Piwulang 8 (1)(2020)
Teaching
http://journal.unnes.ac.id/sju/index.php/piwulang

\title{
PENGEMBANGAN BUKU CERITA RAMAYANA BERBAHASA JAWA SEBAGAI PENUNJANG PEMBELAJARAN SASTRA WAYANG BAGI SISWA TUNAGRAHITA SMPLB DI SEMARANG
}

\author{
Dina Ashlikhatul Kirom¹, Mujimin², Widodo ${ }^{3}$ \\ 1,2,3Jurusan Bahasa Jawa, Fakultas Bahasa dan Seni, Universitas Negeri Semarang, Indonesia \\ Corresponding Author: dyna8194@gmail.com ${ }^{1}$
}

\begin{abstract}
Abstrak
Cerita Ramayana merupakan cerita wayang Jawa yang masuk ke dalam kurikulum 2013 SMP. Kurikulum tersebut digunakan juga di SMP Luarbiasa, khususnya SMPLB C khusus penyandang tunagrahita. Guru SMPLB yang merupakan guru kelas merasa kesusahan untuk memberikan materi pelajaran Ramayana. Kurangnya bahan materi ajar dan minat siswa mempelajari wayang membuat buku cerita wayang Ramayana berbahasa Jawa layak untuk dikembangkan. Berdasarkan angket kebutuhan guru dan siswa, buku cerita Ramayana berbahasa Jawa ini dibutuhkan oleh guru dan siswa. Kemudian dihasilkan buku cerita "Crita Ramayanaku" sesuai dengan judul dan tujuan pembuatannya yang menggunakan bahasa Jawa dan diterjemahkan ke bahasa Indonesia. Buku ini dari segi isi cerita, desain, dan penataan gambar sudah layak dipergunakan berdasarkan penilaian ahli media dan materi. Kemudian buku cerita Ramayana berbahasa Jawa untuk siswa tunagrahita SMPLB di Semarang terbukti efektif digunakan dalam pembelajaran cerita wayang Ramayana.

Kata Kunci: pengembangan, buku cerita, cerita Ramayana, tunagrahita

\section{Abstract}

Ramayana is a story about javannes puppet there in Kurikulum 2013 for Junior High School. Extraordinary Junior High School (SMPLB), specifically mental retardation, used that kurikulum. Teacher of SMPLB is a classroom teacher there was find it difficult using Ramayana's story for lesson. Lack of teaching materials and student interest to learn Ramayana's story make Javanese Ramayana storybook worthy to be developed. Based on the questionnaire, this Javanese Ramayana storybook is needed by teachers and students. Then generated the story book "Crita Ramayanaku" was accordance the title and purpose of the manufactured, that used Javanese language and translated into Indonesian. From the story content, design, and image structur is feasible to use based on the assessment of media experts and materials. Then the Javanese Ramayana storybook for mental retardation students of SMPLB in Semarang proved to be effectively used in learning story of Ramayana.
\end{abstract}

Keywords: development, story book, story of Ramayana, mental retardation 
Dina Ashlikhatul Kirom, dkk/ Piwulang 8 (1) (2020)

\section{PENDAHULUAN}

\begin{tabular}{rrrr}
\multicolumn{2}{r}{ Tunagrahita merupakan anak yang } \\
memiliki $\quad$ keterbelakangan & mental.
\end{tabular}

Keterbelakangan mental tersebut bersangkutan dengan kelainan yang terjadi pada syaraf dan otaknya. Misalkan anak yang bersangkutan berusia dua belas tahun, namun dalam tataran usia mentalnya masih berusia delapan tahun. Namun keterbelakangan mental tersebut tidak harusnya menjadikan anak tunagrahita tidak mendapatkan pengetahuan akan kebudayaan, macam kebudayaan wayang di masyarakat Jawa. Wayang menjadi salah satu pengetahuan kebudayaan yang layak diketahui oleh anak sekolah umum maupun anak berkebutuhan khusus, termasuk penyandang tunagrahita.

Wayang merupakan satu kebudayaan Jawa yang digunakan sebagai cerita pengajaran. Cerita wayang memiliki dua induk cerita, yakni Ramayana dan Mahabarata. Cerita wayang Ramayana dan Mahabarata menjadi satu aset budaya Jawa yang terus menerus berkembang sejak digunakan oleh Sunan Kalijaga dan Raden Patah. Kedua tokoh tersebut mengembangkan cerita wayang sebagai media penyampai dalam pengajaran Islam bagi masyarakat melalui ranah kebudayaan.

Pendidikan dan kebudayaan tersebut dikemas sebagai satu pengajaran yang dimasukkan ke dalam kurikulum bahasa Jawa 2013 tingkat SMP. Penyertaan materi wayang dalam kurikulum ditujukan agar peserta didik mendapatkan pengetahuan kebudayaan. Kurikulum bahasa Jawa 2013 pada tingkat SMP digunakan juga pada sekolah yang sederajat, seperti pada Madrasah Tsanawiyah (MTs), dan sekolah menengah pertama luar biasa (SMPLB).

Kurikulum tidak melihat kebutuhan nyata yang berbeda antara peserta didik di sekolah umum dengan yang berada di pendidikan luar biasa. Pendidikan luar biasa merupakan suatu jenjang pendidikan yang ditujukan khusus untuk anak-anak berkebutuhan khusus, seperti anak penderita gangguan indera pendengar, pengucap, penglihat, maupun gangguan mental macam debil, embisil, ataupun idiot. Anak berkebutuhan khusus tersebut membutuhkan perhatian khusus dalam pendidikan.

Hal tersebut sejalan dengan pendapat Delphie, (2012:56) yang mengatakan bahwa kegiatan layanan pembelajaran terhadap para siswa dengan kesulitan perkembangan, lebih populer disebut dengan tunagrahita, sering mendapatkan kesulitan. Kesulitan-kesulitan tersebut diantaranya dalam membuat program atau rancangan pembelajaran, mencarikan bentuk-bentuk media pembelajaran yang sesuai dengan keberadaan siswa, dan belum ditemukannya cara yang cocok guna meningkatkan kemampuan kognisi sekaligus kemampuan sosial siswa yang bersangkutan.

Selain itu menurut penuturan Siti Suminah, guru SLB Negeri Ungaran, pendidikan luar biasa termasuk lembaga yang jarang diminati untuk dikembangkan penelitian mengenai ilmu pengetahuannya. Padahal anak berkebutuhan khusus justru merupakan anak yang membutuhkan pengembangan ilmu yang lebih intensif. Pengembangan akademis yang sering dilaksanakan di SLB Negeri Ungaran adalah penelitian pendalaman psikologis, bukan hal yang 
Dina Ashlikhatul Kirom, dkk/ Piwulang 8 (1) (2020)

bersifat pengembangan ilmu pengetahuan. Dalam konteks ini yang dimaksudkan ilmu pengetahuan merupakan mata pelajaran yang diberikan, seperti matematika, IPA, IPS, bahasa Indonesia, bahasa Inggris, dan lain sebagainya, termasuk bahasa Jawa.

Keterbatasan itu kurang memberikan pengembangan kepada pola pemberian pelajaran terhadap anak-anak tunagrahita. Para tenaga pengajar merupakan lulusan jurusan pendidikan luar biasa. Tenaga pengajar merasa terbantu jika ada pihak-pihak ahli dari mata pelajaran tertentu, misalnya mata pelajaran bahasa Jawa, yang memberikan pengembangan mendalam untuk pengajaran yang lebih intensif. Guru bahasa Jawa di SLB tersebut juga merupakan guru kelas, bukan guru bidang studi bahasa Jawa.

Salah satu metode pengajaran cerita Ramayana yang mudah ditangkap oleh peserta didik tunagrahita adalah dengan metode membaca. Hal tersebut sama dengan penuturan Suwita (2013) dalam penelitian Efektifitas Media Komik untuk Meningkatkan Kemampuan Membaca Pemahaman bagi Anak Tunagrahita Ringan. Menurut Suwita, pengajaran terhadap tunagrahita dapat pula dilakukan dengan menggunakan media bacaan khusus. Media baca tersebut lebih efektif jika menggunakan komik atau buku cerita bergambar. Akan tetapi tidak ditemukan bacaan yang mudah dan sesuai untuk pengetahuan cerita wayang anak SMPLB.

Berdasarkan permasalahan yang telah diuraikan tersebut, perlu dikembangkan buku bacaan cerita Ramayana ini untuk anak SMPLB yang bisa dijadikan referensi di pembelajaran kurikulum 2013 SMP. Rumusan masalah dalam penelitian ini antaralain: (1) Bagaimana mengetahui karakteristik kebutuhan pengajar dan peserta didik terhadap pengembangan buku cerita Ramayana sebagai penunjang pembelajaran sastra bagi siswa SMPLB di daerah Semarang?, (2) Bagaimana prototipe buku cerita Ramayana sebagai penunjang pembelajaran sastra bagi siswa SMPLB di daerah Semarang?, (3) Bagaimana hasil uji ahli terhadap prototipe buku cerita Ramayana sebagai penunjang pembelajaran sastra bagi siswa SMPLB di daerah Semarang? (4) Bagaimana hasil uji coba terbatas terhadap prototipe buku cerita Ramayana sebagai penunjang pembelajaran sastra bagi siswa SMPLB di daerah Semarang?

\section{METODE PENELITIAN}

Desain penelitian yang digunakan adalah penelitian dan pengembangan atau Research and Development dengan tambahan quasi experimental design. Variabel dalam penelitain ini yakni variabel bebas berupa buku cerita Ramayana berbahasa Jawa yang dikembangkan peneliti serta variabel terikat berupa pengetahuan cerita wayang Ramayana SMPLB kelas VII. Populasi dalam penelitian ini adalah siswa tunagrahita SMPLB di Semarang. Data yang diperoleh menggunakan teknik angket, wawancara, dan teknik tes. Validitas instrumen yang digunakan adalah validitas isi dengan reliabilitas.

Penelitian ini masuk ke dalam kategori penelitian dan pengembangan (Reasearch and Development) dengan tambahan quasi experimental design karena hasil penelitian ini 
Dina Ashlikhatul Kirom, dkk/ Piwulang 8 (1) (2020)

adalah meneliti kebutuhan tunagrahita terhadap buku cerita Ramayana berbahasa Jawa yang kemudian akan dikembangkan dan menjadi hasil akhir penelitian ini. Pendekatan yang digunakan merupakan pendekatan deskriptif kualitatif kuantitif.

Instrumen yang digunakan pada penelitian tersebut berpedoman pada instrumen rubrik penilaian buku pengayaan kepribadiandari pusat penelitian dan pengembangan kementrian pendidikan dan kebudayaan.

Data penelitian ini adalah data analisis kebutuhan, uji validasi prortotipe, dan tes uji coba terbatas. Data analisis kebutuhan diambil dari hasil wawancara, observasi, dan angket kebutuhan dengan guru dan siswa SMPLB. Data validasi diambil dari hasil uji coba terbatas dengan pengisian instrumen berupa angket validasi ahli media dan materi. Sedangkan data tes diambil dari hasil uji coba terbatas terhadap siswa SMPLB C Negeri Ungaran kelas VII berupa pretest dan postest.

Teknik yang akan digunakan untuk mengumpulkan data dalam penelitian ini adalah teknik observasi, wawancara, angket, dan tes.

Adapun langkah-langkah yang dilakukan penelitian ini adalah (1) survey pendahuluan atau analisis potensi dan masalah yakni mendefinisikan tujuan untuk produk atau program instruksional yang termasuk analisis kebutuhan, serta menganalisis potensi dan masalah; (2) Mengumpulkan informasi, Hal ini dilakukan dengan pengumpulan data kebutuhan siswa dengan angket; (3) Desain produk. Pendesainan produk yang dilakukan yaitu membuat prototipe sesuai dengan pertimbangan kerangka pada angket kebutuhan. Desain produk ini sudah mencakup kegiatan lanjutan membuat buku cerita Ramayana berbahasa Jawa sebagai media penunjang pembelajaran sastra wayang untuk siswa tunagrahita SMPLB di Semarang secara konkrit.

Desain produk diawali dengan pembuatan gambar secara manual menggunakan pena yang kemudian di masukkan ke dalam file dan diedit menggunakan aplikasi adobe photoshop; (4) Penilaian terbatas atau validasi desain prototipe buku cerita Ramayana berbahasa Jawa sebagai media penunjang pembelajaran sastra wayang untuk siswa tunagrahita SMPLB di Semarang. Tahap ini merupakan tahap penilaian oleh sejumlah guru dan ahli secara terbatas; (5) Revisi dan perbaikan desain, merupakan proses merevisi kesalahan-kesalahan setelah melakukan penilaian produk atau prototipe oleh ahli dan guru;

dan (6) Uji coba terbatas yang dilanjutkan dengan deskripsi hasil penelitian, yaitu mendeskripsikan penggunaan buku cerita Ramayana berbahasa Jawa sebagai media penunjang pembelajaran sastra wayang untuk siswa tunagrahita SMPLB di Semarang. Pengambilan nilai dari uji coba ini merupakan nilai pengetahuan siswa dalam memahami isi cerita serta nilai ketrampilan membaca yang merupakan potensi siswa tunagrahita ringan dalam pemerolehan bahasanya.

\section{HASIL DAN PEMBAHASAN}

Hasil buku cerita Ramayana berbahasa Jawa untuk Siswa SMPLB C di Semarang, yakni: a) Dihasilkan buku cerita Ramayana berbahasa Jawa sesuai judul dan tujuan pembuatan buku, 
Dina Ashlikhatul Kirom, dkk/ Piwulang 8 (1) (2020)

dengan menggunakan bahasa Jawa disertai terjemah bahasa Indonesia ; (b) Hasil uji coba Buku cerita Ramayana berbahasa Jawa untuk siswa tunagrahita SMPLB di Semarang yang kemudian terbukti efektif setelah diujicobakan keefektifannya dalam pembelajaran pengetahuan cerita wayang Ramayana pada siswa kelas VIII SMPLB Negeri 1 Ungaran. Hal ini dapat dilihat dari penambahan rata-rata nilai postest kelompok kontrol setelah diberi perlakuan adalah 13,33, adapun penambahan rata-rata nilai postest kelompok eksperimen setelah diberi perlakuan adalah 23,33.

Adapun hal yang dibahas dalam penelitian ini antaralain: (1) pengumpulan informasi tentang kebutuhan anak dan guru terhadap buku cerita Ramayana berbahasa Jawa untuk siswa tunagrahita SMPLB di Semarang, (2) hasil buku cerita Ramayana berbahasa Jawa untuk siswa tunagrahita, dan (3) hasil uji coba terbatas buku cerita Ramayana berbahasa Jawa untuk siswa tunagrahita.

\section{Data Kebutuhan Siswa dan Guru terhadap buku} cerita Ramayana berbahasa Jawa untuk siswa tunagrahita SMPLB di Semarang

Data kebutuhan terhadap buku cerita Ramayana berbahasa Jawa untuk siswa tunagrahita SMPLB di Semarang diperoleh melalui angket berisi beberapa pertanyaan. Angket kebutuhan ditujukan kepada anak usia sekolah menengah pertama yang menyandang tunagrahita dan gurunya.

\section{Kebutuhan Siswa}

$\begin{array}{rrrr}\text { Kebutuhan buku cerita } & \text { Ramayana } \\ \text { berbahasa Jawa untuk siswa tunagrahita }\end{array}$

ditanyakan kepada 20 anak dari SMPLB N Ungaran, SMPLB C Widya Bhakti Semarang, dan SMPLB Pelita Ilmu. Siswa diajukan pertanyaan berjumlah 12 pertanyaan. Bersambungan dengan pengetahuan siswa akan wayang, siswa mengetahui wayang hanya sebatas cerita mahabarata. Hasil angket menyebutkan $75 \%$ siswa mengetahui wayang sebatas pandhawa, 15\% hanya tahu tentang arjuna, dan 0\% untuk Rama dan Sinta. Pada ketertarikan siswa terhadap wayang, 19 siswa mengaku senang membaca serta mengetahui cerita wayang dan hanya 1 orang yang menjawab tidak.

Hal lain yang ditanyakan adalah bagaimana cara guru menceritakan wayang. Menurut penuturan siswa dari ketiga sekolah, $30 \%$ menjawab guru sering bercerita langsung, $20 \%$ menggunakan komputer, dan 50\% menjawab pengenalan menggunakan gambar saja. Jawaban mereka untuk pertanyaan pembelajaran yang menyenangkan adalah $45 \%$ suka mendengarkan guru bercerita dari buku, sedangkan $55 \%$ menjawab suka membacanya jika dari sebuah buku bergambar yang mudah dipahami.

Penyusunan naskah cerita buku Crita Ramayanaku diinginkan dari 20 siswa, 10 anak menginginkan naskah cerita berbahasa Jawa ngoko disertai terjemahan dalam bahasa Indonesia, berbahasa Jawa krama alus 6 anak, 3 anak berbahasa Jawa ngoko saja, dan 1 anak menginginkan bahasa Jawa ngoko disertai terjemahan bahasa Jawa krama. 65\% anak berharap dapat lebih tertarik dengan wayang setelah dibuatkan buku Crita Ramayanaku dan 
Dina Ashlikhatul Kirom, dkk/ Piwulang 8 (1) (2020)

$35 \%$ berharap dapat belajar wayang dengan lebih mudah menggunakan buku tersebut.

\section{Kebutuhan Guru}

Berdasarkan jawaban angket kebutuhan guru dapat diketahui bahwa guru sebanyak 100\% (empat orang) menilai bahwa dalam mengajarkan cerita wayang Ramayana maupun mengenalkan tokoh-tokohnya dalam pembelajaran selama ini berlangsung belum efektif bagi anak-anak berkebutuhan khusus tipe tunagrahita. Keempat guru merasa kesulitan terutama dalam mengajarkan cerita wayang Ramayana dan siswa dirasa kurang mengenal cerita Ramayana.

Media maupun buku bacaan berceritakan Ramayana yang selama ini digunakan masih berfokus pada cerita yang lengkap dan bertele-tele. $100 \%$ guru mengemukakan menggunakan bahan materi pengajaran Ramayana dari buku ajar. Guru susah mencari bahan yang dijadikan pengajaran, keempat guru lebih suka mengajarkan cerita wayang Mahabarata, karena tokoh-tokoh dalam cerita Mahabarata lebih familiar dibanding Ramayana.

Manfaat yang diperoleh dari pembuatan buku cerita Ramayana diharapkan menjadi tidak monoton seperti jawaban $100 \%$ yang diberikan keempat guru saat diberi pertanyaan manfaat apa yang diperoleh dari buku cerita tersebut. Bersesuaian dengan harapan yakni siswa dapat lebih tertarik dalam mempelajari cerita Ramayana, karena 100\% guru menjawab hal yang sama.

\section{Hasil Buku Cerita Ramayana Berbahasa Jawa untuk Siswa Tunagrahita SMPLB di Semarang}

Prototipe buku cerita Ramayana berbahasa Jawa untuk Siswa Tunagrahita SMPLB di Semarang berupa buku cerita tentang wayang Ramayana bergambar yang ditujukan untuk siswa berkebutuhan khusus tipe tunagrahita. Buku ini menggunakan bahasa Jawa dengan terjemah bahasa Indonesia. Pada tahap awal penulis naskah memilih lima cerita yang diangkat, yakni "Rama lan Sinta", "Jathayu", "Sugriwa Subali", "Anoman Obong", dan "Kepanggihe Rama Sinta". Penulis naskah yang juga sebagai ilustrator dan satu ilustrator lain membaca cerita tersebut untuk menemukan bagian cerita mana saja yang akan dibuat sebuah komik.

Langkah berikutnya, penulis naskah menentukan naskah cerita untuk mempermudah menentukan jumlah panel yang diperlukan dari setiap subcerita. Langkah ketiga yang ditempuh yakni penggambaran kedua ilustrator dengan membagi bagian masing-masing berdasarkan naskah yang telah dibuat.

Setelah gambar yang masih berupa sketsa kasar jadi, penulis naskah dan ilustrator mendiskusikan lagi tentang kesesuaian gambar dengan naskah, penulis naskah sekaligus ilustrator memasukkan gambar ke dalam aplikasi adobe photoshop CS3. Langkah terakhir pembuatan gambar merupakan finishing serta pemberian warna terhadap sub-cover dibantu satu ilustrator lagi yang berperan melakukan finishing. Kemudian gambar masuk ke dalam tahap layout, yakni penyatuan gambar dengan naskah. 
Dina Ashlikhatul Kirom, dkk/ Piwulang 8 (1) (2020)

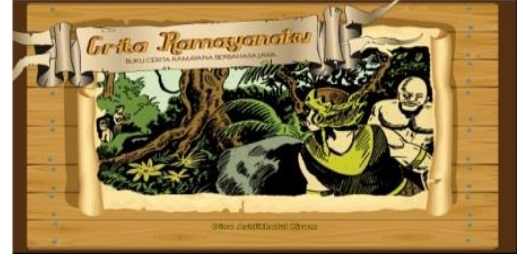

Gambar 1. Cover depan buku cerita

Buku Crita Ramayanaku berisikan 40

halaman yang terdiri dari halaman sampul, preliminaries, halaman isi, dan halaman jati diri penulis. Pada halaman isi terdiri dari sub-cover, dan isi cerita. Cerita yang pertama berjudul "Rama Sinta", menceritakan tentang pertemuan Rama dan Sinta. Sinta yang tengah diperebutkan dalam sebuah sayembara mengangkat gandhewa akhirnya dimenangkan oleh Rama wijaya.

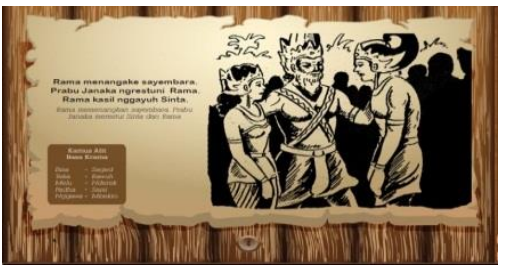

Gambar 2. Cuplikan cerita pada waktu Rama dan Sinta direstui Prabu Janaka

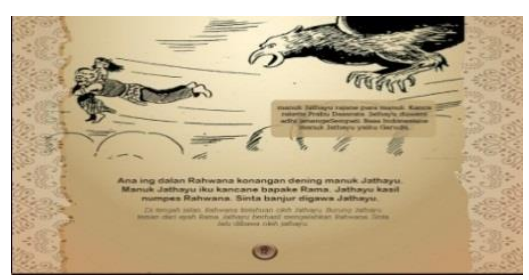

Gambar 3. Cuplikan cerita pada saat Jathayu ingin menyelamatkan Sinta dari Rahwana

Cerita kedua "Jathayu" secara garis besar menceritakan cuplikan kehidupan Rama dan Sinta yang ditemani Lesmana di dalam hutan, dan berakhir dengan penculikan Sinta oleh Rahwana. Jathayu yang melihatnya berusaha menolong, sampai akhirnya ia tumbang dan jatuh ke hutan. Pada subcerita ketiga berjudul "Sugriwa Subali" merupakan lanjutan dari dua cerita sebelumnya, mengenai peperangan antara dua monyet kakak beradik karena perebutan kekuasaan.

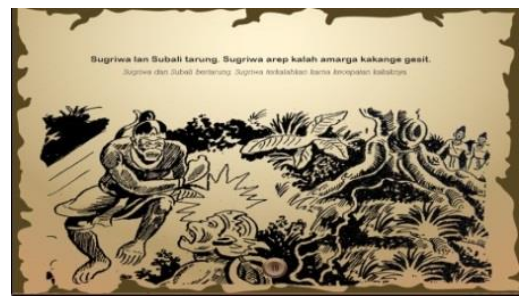

Gambar 4. Cuplikan Peperangan Sugriwa dan Subali

\section{Pada Anoman Obong diceritakan} bagaimana perjuangan Rama mengutus Anoman sebagai mata-mata untuk pergi ke Alengka. Anoman memastikan keberadaan Sinta serta sekaligus memberi peringatan dengan membakar sebagian kerajaan Alengka.

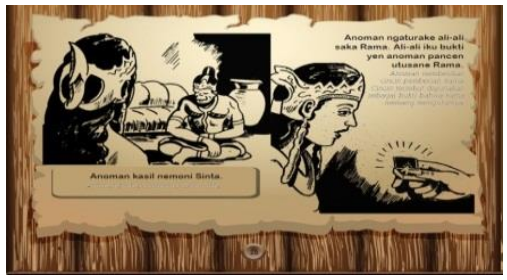

Gambar 5. Pada saat Anoman datang ke Alengka dan bertemu Dewi Sinta

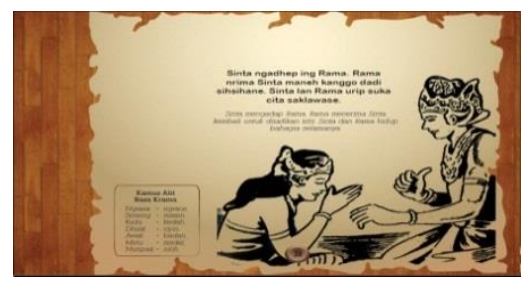

Gambar 6. Pada saat Rama dan Sinta akhirnya bersatu

Cerita Ramayana ini berakhir dengan subcerita yang kelima yakni "Ketemune Rama Sinta". Garis besar cerita ini menjelaskan kemenangan Rama dan pasukannya membawa 
Dina Ashlikhatul Kirom, dkk/ Piwulang 8 (1) (2020)

pulang kembali Sinta. Namun sebelum akhirnya dia menerima Sinta kembali, Sinta harus disucikan terlebih dahulu ke dalam api suci. Ketika Sinta terbukti masih suci dengan keluar dari api dalam kondisi bersih, Rama dan Sinta akhirnya bisa bersatu kembali dan hidup bahagia.

Buku Crita Ramayanaku juga disertai dengan pembelajaran bahasa krama pada kolomkolom imbuhan, serta unggah-ungguh pada narasinya. Buku ini disertai dengan pengenalan tokoh pada kolom imbuhan di beberapa halaman. Buku Crita Ramayanaku diperuntukkan anak tunagrahita dengan mempertimbangkan penggunaan bahasa khusus seperti meminimalkan penggunaan kata ganti serta penyusunan kalimat yang pendek dan mudah dipahami.

\section{Nilai Uji Coba Pretest dan Postest Kelompok} Eksperimen dan Kontrol

Uji coba dilakukan di SMPLB Negeri Ungaran pada kelas VII. Kelas tersebut dibagi menjadi 2 kelompok, yakni kelompok eksperimen dan kelompok kontrol.

Kelompok eksperimen merupakan kelompok yang dipergunakan sebagai kelompok uji coba terbatas terhadap buku cerita Ramayana untuk siswa tunagrahita SMPLB di Semarang. Sedangkan kelompok kontrol merupakan kelompok yang tidak mengikuti pembeljaran pengetahuan wayang Ramayana tanpa menggunakan media buku cerita Ramayana berbahasa Jawa untuk siswa tunagrahita SMPLB di Semarang. Tes awal pada kelompok eksperimen dan kontrol dilaksanakan bersama pada hari Jumat, tanggal 29 September 2017, jam pelajaran ke 4 dan 5. Jumlah siswa yang mengikuti tes awal 12 siswa, 6 siswa kelompok eksperimen dan 6 siswa kelompok kontrol.

Tes akhir dilakukan setelah diberikan perlakuan dengan menggunakan produk berupa buku Crita Ramayanaku pada kelompok eksperimen. Pemberian tes akhir ini tetap dilakukan pada kelompok eksperimen dan kontrol. Tujuan tes akhir adalah untuk mengetahui hasil pencapaian pembelajaran pengetahuan wayang Ramayana dengan dan tanpa menggunakan produk buku cerita Ramayana berbahasa Jawa. Tes akhir pada kelompok eksperimen dilaksanakan pada hari Selasa, 3 Oktober 2017, jam ke 6 dan 7. Jumlah siswa yang mengikuti tes akhir sebanyak 6 siswa. Tes akhir kelompok kontrol yang dilaksanakan pada hari Rabu, 4 Oktober 2017 jam pelajaran ke 1 dan 2 yang diikuti oleh 6 siswa. Berikut rekapitulasi nilai yang diperoleh kedua kelompok.

\begin{tabular}{|c|c|c|c|c|}
\hline \multirow{2}{*}{ Data } & \multicolumn{2}{|c|}{ Tes awal } & \multicolumn{2}{c|}{ Tes akhir } \\
\cline { 2 - 5 } & $\begin{array}{c}\text { Eksperim } \\
\text { en }\end{array}$ & $\begin{array}{c}\text { Kon- } \\
\text { trol }\end{array}$ & $\begin{array}{c}\text { Ekspe- } \\
\text { rimen }\end{array}$ & $\begin{array}{c}\text { Kon- } \\
\text { trol }\end{array}$ \\
\hline $\mathrm{N}$ & 6 & 6 & 6 & 6 \\
\hline $\begin{array}{c}\text { Skor } \\
\text { terti- } \\
\text { nggi }\end{array}$ & 80 & 60 & 90 & 70 \\
\hline $\begin{array}{c}\text { Skor } \\
\text { teren- } \\
\text { dah }\end{array}$ & 30 & 40 & 60 & 50 \\
\hline Mean & 51,6667 & 46,6667 & 75 & 60 \\
\hline $\begin{array}{c}\text { Medi- } \\
\text { an }\end{array}$ & 45 & 45 & 75 & 60 \\
\hline Mode & 40 & 40 & 80 & 70 \\
\hline $\begin{array}{c}\text { Std. } \\
\text { Devi-asi }\end{array}$ & 19,407902 & 8,16496 & 10,488088 & 8,99442 \\
5809 & 48 & 719 \\
\hline
\end{tabular}

Berdasarkan tabel di atas, dapat dilihat

bahwa skor mean tes awal kelompok eksperimen 
Dina Ashlikhatul Kirom, dkk/ Piwulang 8 (1) (2020)

sebesar 51,67. Sementara itu, skor mean tes akhir pada kelompok eksperimen mengalami kenaikan menjadi 75. Hal ini menunjukkan adanya peningkatan setelah perlakuan pada kelompok eksperimen. Kenaikan mean pada kelompok eksperimen sebesar 23,33. Skor median tes awal kelompok eksperimen sebesar 45 mengalami kenaikan pada tes akhir menjadi 75. Begitu pula dengan skor mode yang juga mengalami kenaikan skor dari 40 menjadi 80 . Skor tertinggi tes awal pada kelompok eksperimen sebesar 80 dan skor terendah sebesar 30. Sementara pada tes akhir kelompok eksperimen skor tertinggi sebesar 90 dan skor terendah sebesar 60 .

Mean tes awal kelompok kontrol sebesar 46,67. Sementara itu, mean tes akhir pada kelompok kontrol mengalami peningkatan menjadi 60. Hal ini menunjukkan adanya peningkatan setelah pembelajaran dalam kelompok kontrol. Kenaikan mean pada kelompok kontrol sebesar 13,33. Skor median tes awal kelompok kontrol sebesar 45 mengalami kenaikan skor pada tes akhir menjadi 60 , adapun skor mode juga mengalami kenaikan dari 45 menjadi 70. Skor tertinggi tes awal pada kelompok kontrol sebesar 60 dan skor terendah sebesar 70. Pada tes akhir kelompok kontrol skor tertinggi 40 dan skor terendah sebesar 50 .

\section{Hasil Olah Data Nilai Uji Coba Terbatas} Kelompok Eksperimen dan Kontrol

Suatu instrumen penelitian dikatakan memiliki nilai reliabilitas tinggi, apabila tes yang dibuat mempunyai hasil konsisten dalam mengukur hal yang hendak diukur. Hal ini berarti semakin reliabel suatu tes memiliki persyaratan maka semakin yakin kita dapat menyatakan bahwa dalam hasil suatu tes mempunyai hasil yang sama ketika dilakukan tes kembali. Tes pengetahuan cerita wayang Ramayanaakan dihitung dengan menggunakan program SPSS 20.0. hal tersebut dapat dilihat dalam SPSS pada Cronbach's Alpha> 0.60. Dapat disimpulkan bahwa konstruk pertanyaan pada item angket tersebut berkategori reliabel apabila Cronbach's Alpha $>0.60$. Berikut Uji reliabilitas tes awal dan tes akhir kelompok eksperimen dan kontrol.

Tes awal kelompok eksperimen sebesar memiliki nilai reliabilitas 0,617 , tes awal kelompok kontrol sebesar 0,750 , tes akhir kelompok eksperimen sebesar 0,619, dan tes akhir kelompok kontrol sebesar 0,678. Hal tersebut menunjukan semua hasil lebih dari 0,60 yang berarti bahwa tes tentang pengetahuan cerita wayang Ramayana sudah reliabel.

Kemudian dilakukan pengujian hipotesis untuk mengetahui perbedaan antara kelompok yang mengikuti pembelajaran pengetahuan cerita wayang Ramayana menggunakan dan tanpa menggunakan produk buku cerita Ramayana berbahasa Jawa untuk siswa tunagrahita SMPLB di Semarang. Selain itu, analisis data juga digunakan untuk menguji keefektifan penggunaan produk buku cerita Ramayana berbahasa Jawa untuk siswa tunagrahita SMPLB di Semarang pada pembelajaran KD cerita wayang Ramayana siswa kelas VIII SMPLB Negeri Ungaran. Dalam penelitian ini, peneliti menggunakan bantuan program SPSS 20.0

Berikut adalah tabel hasil uji-t data tes awal pengetahuan cerita wayang Ramayana antara kelompok eksperimen dan kelompok kontrol. 
Dina Ashlikhatul Kirom, dkk/ Piwulang 8 (1) (2020)

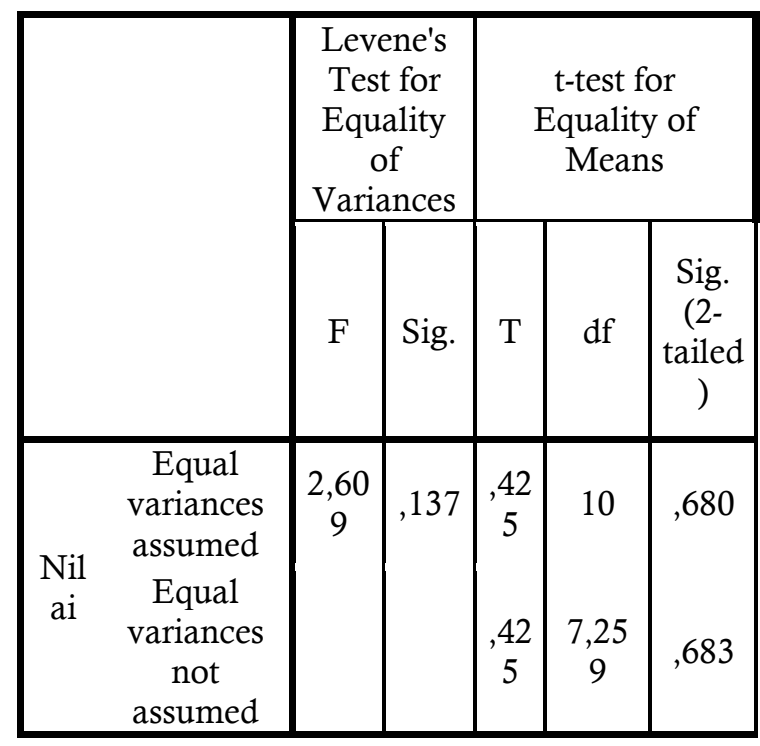

Berdasarkan tabel di atas dapat diketahui sig (2-tailed) atau probabilitas sebesar 0,680 dan 0,683 adapun taraf signifikansinya sebesar 0,05 (5\%). Hal ini menunjukkan nilai probabilitas lebih besar dari nilai taraf signifkansi $(0,680>0,05)$. Berdasarkan kriteria pengujian yang telah ditetapkan, yaitu jika probabilitas $>0,05$, maka HO diterima. Maka dapat disimpulkan, bahwa hasil uji-t pada datapretest kelompok kontrol dan kelompok eksperimen tidak menunjukkan perbedaan kemampuan pengetahuan cerita wayang Ramayana. Dengan kata lain, keadaan awal pengetahuan cerita wayang Ramayana pada pretest adalah sama atau setara.

Berikut merupakan tabel hasil uji-t data tes akhir pengetahuan cerita wayang Ramayana antara kelompok eksperimen dan kelompok kontrol.

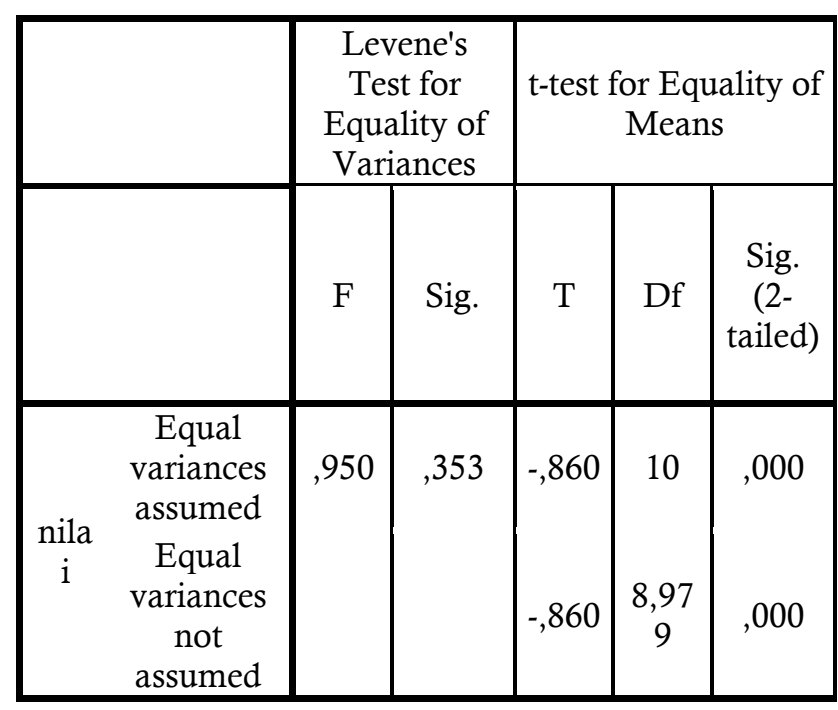

Dari tabel di atas dapat diketahui signifikansi (2-tailed) atau probabilitas sebesar 0,000 , adapun taraf signifikansinya sebesar 0,05 (5\%). Hal ini menunjukkan nilai probabilitas lebih kecil dari nilai taraf signifkansi $(0,000>0,05)$. Berdasarkan kriteria pengujian yang telah ditetapkan, yaitu: jika probabilitas $<0,05$, maka H0 ditolak. Maka dapat disimpulkan, bahwa hasil uji-t pada data postest kontrol dan posttest eksperimen menunjukkan adanya perbedaan kemampuan menulis teks deskriptif. Dengan kata lain, keadaan akhir pengetahuan cerita wayang Ramayana pada kelompok kontrol dan eksperimen adalah berbeda.

Dapat diketahui sig (2-tailed) atau probabilitas sebesar 0,000 sedangkan taraf signifikansinya sebesar $0,05 \quad(5 \%)$. Hal ini menunjukkan nilai probabilitas lebih kecil dari nilai taraf signifkansi $(0,000>0,05)$. Berdasarkan kriteria pengujian yang telah ditetapkan, yaitu: jika probabilitas < 0,05, maka H0 ditolak. Maka dapat disimpulkan, bahwa hasil uji-t pada data pretest dan posttest menunjukkan adanya 
Dina Ashlikhatul Kirom, dkk/ Piwulang 8 (1) (2020)

perbedaan pengetahuan cerita wayang Ramayana. Dengan kata lain, keadaan awal dan keadaan akhir pengetahuan cerita wayang Ramayana pada kelompok eksperimen adalah berbeda.

Kemudian dapat diketahui sig (2-tailed) atau probabilitas sebesar 0,000 sedangkan taraf signifikansinya sebesar 0,05 (5\%). Hal ini menunjukkan nilai probabilitas lebih kecil dari nilai taraf signifkansi $(0,000>0,05)$.

Berdasarkan kriteria pengujian yang telah ditetapkan, yaitu: jika probabilitas $<0,05$, maka H0 ditolak. Maka dapat disimpulkan, bahwa hasil uji-t pada data pretest dan posttest kelompok kontrol menunjukkan adanya perbedaan pengetahuan cerita wayang Ramayana. Dengan kata lain, keadaan awal dan keadaan akhir pengetahuan cerita wayang Ramayana pada kelompok kontrol adalah berbeda.

\section{SIMPULAN}

Analisis angket kebutuhan anak tunagrahita terhadap media buku cerita Ramayana berbahasa Jawa untuk siswa tunagrahita SMPLB di Semarang, 30 siswa (100\%) mengetahui apa itu wayang dan memperhatikan bagaimana pembelajarannya. 24 siswa (80\%) memiliki minat mempelajari wayang, 21 siswa (70\%) menginginkan buku cerita bergambar, dan 30 siswa (100\%) menginginkan pembuatan buku cerita Ramayana berbahasa Jawa ngoko dan Indonesia. Pada hasil analisis angket kebutuhan guru, keempat guru kelas tunagrahita $100 \%$ mengetahui apa itu wayang dan mengajarkannya pada anak, tiga orang (75\%) mengatakan anak belum paham betul wayang, empat guru (100\%) menyatakan kurang memiliki bahan ajar mengenai wayang, dan 100\% memberikan saran pemmbuatan buku cerita dengan dua bahasa disertai gambar masingmasing ceritanya.

Kemudian dihasilkan sebuah prototipe buku cerita Ramayana berbahasa Jawa dengan terjemah Indonesia yang singkat dan jelas, serta memuat gambar yang dapat dipahami. Buku cerita berjudul "Cerita Ramayanaku". Sesuai dengan judul dan tujuan pembuatannya, buku cerita ini diangkat dari cerita klasik wayang Ramayana dengan 5 subcerita yang bersumber dari cerita Ramayana versi pewayangan Jawa. Pembuatan kalimat dalam buku cerita ini menyesuaikan kemampuan siswa tunagrahita dalam memahami kalimat. Buku cerita ini memuat beberapa catatan kecil pada beberapa halaman sebagai teks pengenalan wayang dan pembelajaran bahasa Jawa krama. Ukuran buku cerita ini adalah A5 dengan penjilidan model jilid tengah.

Berdasarkan penilaian ahli materi dan media, isi buku cerita Ramayana berbahasa Jawa untuk siswa tunagrahita ini dinyatakan layak sebagai buku pengayaan cerita wayang Ramayana. Namun, perlu adanya perbaikan naskah cerita yang lebih mudah dipahami dan sesuai dengan kaidah penulisan bahasa Jawa dan bahasa Indonesia yang benar.

Adapun uji coba dilakukan pada siswa kelas VII SMPLB Negeri Ungaran. Hasil yang diperoleh dari jumlah rata-rata nilai postest kelompok kontrol setelah diberi perlakuan adalah 
Dina Ashlikhatul Kirom, dkk/ Piwulang 8 (1) (2020)

13,33, adapun jumlah rata-rata nilai postest kelompok eksperimen setelah diberi perlakuan adalah 23,33. Hal tersebut membuktikan buku cerita Ramayana berbahasa Jawa untuk siswa tunagrahita SMPLB di Semarang efektif digunakan dalam pembelajaran $\mathrm{KD}$ cerita wayang Ramayana kurikulum 2013.

\section{DAFTAR PUSTAKA}

Alexio, Paul dan Claire Norris. 2007. Coimics, Reading, and Primary Aged Children. http://shev.org.uk/sites/sheu.org.uk/files/i magepicker/1/eh254pacn.pdf. Diakses pada Akses 4 Maret 2017.

Alwi, Hasan, dkk. 2007. Kamus Besar Bahasa Indonesia. Balai Pustaka: Jakarta

D.M., Sunardi. 1979. Ramayana. Balai Pustaka: Jakarta

Delphie, Bandi. 2012. Pembelajaran Anak Tunagrahita: Suatu Pengantar dalam Pendidikan Inklusi. Refika Aditama: Bandung.

Kartono, Kartini. 1989. Psikologi Abnormal dan Abnormalitas Seksual. Penerbit Mandiri Maju: Bandung.

Latuheru, J.D. 1993. Media Pembelajaran dalam Proses Belajar Mengajar Kini.Penerbit IKIP Ujung Pandang: Ujung Pandang.

Muslich, Masnur. 2010. Text Book Writing. Ar Ruz Media: Jogjakarta

Nanda M.H. 2010. Wayang. Bintang Cemerlang: Yogyakarta.

Pusat Kurikulum dan Perbukuan. 2014. Instrumen dan Rubrik B3 Penliaian Buku Pengayaan Kepribadian. Pusat Kurikulum dan Perbukuan Badan Penelitian dan Pengembangan Kementrian Pendidikan dan Kebudayaan: Jakarta

Sugiyono. 2015. Metode Penelitian Pendidikan: Pendekatan Kuantitatif, Kualitatif, dan R\&D. Alfabeta: Bandung

Sukestiyarno. 2010. Statistika Dasar. Universitas Negeri Semarang: Semarang

Suswita. 2013. Skripsi: Efektifitas Media Komik untuk Meningkatkan Kemampuan Membaca Pemahaman bagi Anak Tunagrahita Ringan. Jogjakarta.
Widoyoko, Eko Putro. 2015.Evaluasi Program Pembelajaran. Pustaka Pelajar: Jogjakarta.

Zoetmulder, P.J. 1985. Kalangwan. Djambatan: Jakarta. 